\title{
Sub-micron atmospheric aerosols in the surroundings of Marseille and Athens: physical characterization and new particle formation
}

\author{
T. Petäjä ${ }^{1}$, V.-M. Kerminen ${ }^{2}$, M. Dal Maso ${ }^{1}$, H. Junninen ${ }^{1}$, I. K. Koponen ${ }^{1,3}$, T. Hussein ${ }^{1,4}$, P. P. Aalto ${ }^{1}$, \\ S. Andronopoulos ${ }^{5}$, D. Robin ${ }^{6}$, K. Hämeri ${ }^{1,7}$, J. G. Bartzis ${ }^{5,8}$, and M. Kulmala ${ }^{1}$ \\ ${ }^{1}$ Division of Atmospheric Sciences, Dept. of Physical Sciences, University of Helsinki, Finland \\ ${ }^{2}$ Finnish Meteorological Institute, Climate and Global Change, Helsinki, Finland \\ ${ }^{3}$ Department of Chemistry, University of Copenhagen, Denmark \\ ${ }^{4}$ Dept. of Applied Environmental Sciences (ITM), Stockholm University, Stockholm, Sweden \\ ${ }^{5}$ National Centre for Scientific Research "Demokritos", Athens, Greece \\ ${ }^{6}$ AIRMARAIX, Marseille, France \\ ${ }^{7}$ Finnish Institute of Occupational Health, Helsinki, Finland \\ ${ }^{8}$ Department of Engineering and Management of Energy Resources, University of West Macedonia, Kozani, Greece
}

Received: 31 July 2006 - Published in Atmos. Chem. Phys. Discuss.: 13 September 2006

Revised: 30 January 2007 - Accepted: 21 April 2007 - Published: 23 May 2007

\begin{abstract}
The properties of atmospheric aerosol particles in Marseille and Athens were investigated. The studies were performed in Marseille, France, during July 2002 and in Athens, Greece, during June 2003. The aerosol size distribution and the formation and growth rates of newly formed particles were characterized using Differential Mobility Particle Sizers. Hygroscopic properties were observed using a Hygroscopic Tandem Differential Mobility Analyzer setup. During both campaigns, the observations were performed at suburban, almost rural sites, and the sites can be considered to show general regional background behavior depending on the wind direction. At both sites there were clear pattern for both aerosol number concentration and hygroscopic properties. Nucleation mode number concentration increased during the morning hours indicating new particle formation, which was observed during more than $30 \%$ of the days. The observed formation rate was typically more than $1 \mathrm{~cm}^{-3} \mathrm{~s}^{-1}$, and the growth rate was between $1.2-9.9 \mathrm{~nm} \mathrm{~h}^{-1}$. Based on hygroscopicity measurements in Athens, the nucleation mode size increase was due to condensation of both water insoluble and water soluble material. However, during a period of less anthropogenic influence, the growth was to a larger extent due to water insoluble components. When urban pollution was more pronounced, growth due to condensation of water soluble material dominated.
\end{abstract}

Correspondence to: T. Petäjä

(tuukka.petaja@helsinki.fi)

\section{Introduction}

Atmospheric aerosol particles effect the global climate directly by scattering incoming solar radiation and indirectly by acting as a cloud condensation nuclei (CCN). Regionally, suspended particulate matter deteriorate visibility (Cabada et al., 2004) and affect human health (Brunekreef and Holgate, 2002; Von Klot et al., 2005). The net effects depend on the amount of particles, their chemical composition, and their physical size.

Sub-micron particle population is renewed both by primary (Kittelson et al., 2004) and by secondary sources i.e. gas-to-particle conversion (Kulmala et al., 2004b). Both anthropogenic sources (Kittelson et al., 2004; Janhäll and Hallquist, 2005) and biogenic sources (Tunved et al., 2006) contribute to the amount of suspended sub-micron aerosol particle number concentration.

Independent of their origin, these fresh atmospheric particles are quite inefficient in their ability to scatter incoming solar radiation or act as CCNs. However, as they grow in size due to e.g. condensational growth, they start to contribute remarkably. Based on measurements and regional modeling, in the Po Valley region, Italy, Laaksonen et al. (2005) estimated that the production of $\mathrm{CCN}$ via gas-to-particle conversion and subsequent growth to $100 \mathrm{~nm}$ sizes was comparable with CCN originating from primary sources. Similarly, O'Dowd (2001) estimated that intensive new particle formation bursts at the Irish coastline in Mace Head were able to produce a three-fold increase in particle number concentration above $50 \mathrm{~nm}$ in diameter. In this size range particles can activate to $\mathrm{CCN}$, if they are hygroscopic enough (e.g. Bilde

Published by Copernicus GmbH on behalf of the European Geosciences Union. 
and Svenningsson, 2004). Thus, new particle formation can produce particles large enough to act as $\mathrm{CCN}$.

In assessment of the ambient aerosol potential for $\mathrm{CCN}$ production, global models (Stier et al., 2005) have to be utilized. Regional air quality models (Sotiropoulou et al., 2004) can be put to use to calculate e.g. particulate pollution and ozone exposure of population in the modeling domain. Both of these applications need measured properties of ambient aerosol particle population and hygroscopicity as input parameters (Putaud et al., 2004). Recently, Van Dingenen et al. (2004) consolidated aerosol mass concentrations and size distribution measurements conducted in Europe at 31 different sites. However, according to Van Dingenen et al. (2004), physical characterization data is lacking in Eastern Europe and in the Mediterranean Area. This gap has been partly filled in terms of aerosol mass, chemical composition, and total number concentration by Cachier et al. (2005) and Marinoni et al. (2005), who conducted aerosol characterization as a part of ESCOMPTE (Cros et al., 2004) project in the Marseille area. Average properties of number size distribution in the Marseille area is still lacking as well as the hygroscopic properties of the sub-micron particles.

Previously reported air quality studies in Athens area has focused on either particulate mass concentrations (Chaloulakou et al., 2003; Grivas et al., 2004), inorganic composition of super-micron mass (Colbeck et al., 2002), or ozone (Flocas et al., 2003). The aerosol number size distribution data below $1 \mu \mathrm{m}$ is lacking. Flocas et al. (2006) mapped total number concentrations in the Greater Athens Area from an airplane using optical methods. However, the number concentration in an urban environment is typically dominated by particles smaller than the lower detection limit of their instrument $(0.1 \mu \mathrm{m})$.

We investigated aerosol number size distributions, hygroscopic growth factors, and the formation and growth rates of nucleation mode aerosols based on two field campaigns from 1-19 July 2002, (Day of Year, DOY 182-200) and in 11-26 June 2003 (DOY 162-177) in Marseille and Athens, respectively. These campaigns were part of Biogenic Aerosols and Air Quality in the Mediterranean Area (BOND) project. In this paper, average characteristics of sub-micron aerosol modal properties and hygroscopic properties of selected Aitken sizes are presented in order to produce input data for regional air quality models concerning an average summer background particulate population. The second aim of the study is to quantify the formation rates of nucleation mode particles and their subsequent growth at both sites. The related condensable vapour concentrations and source rates are also described. Based on hygroscopicity data for the nucleation mode, the relative importance of water-soluble and water-insoluble components to the detected growth of the new mode is evaluated.

\section{Experimental}

\subsection{Measurement sites}

Two intensive field campaigns in the Mediterranean area were conducted during the BOND project (Fig. 1). The first campaign was held in Marseille, France, during 1-19 July 2002 (Day of Year, DOY 182-200) and the second in Athens, Greece, during 11-26 June 2003 (DOY 162-177). In Marseille the site was located in Plan d'Aups village $\left(43^{\circ} 19^{\prime} \mathrm{N}\right.$, $5^{\circ} 42^{\prime} \mathrm{E}, 700 \mathrm{~m}$ above sea level, $\mathrm{m}$ a.s.l., approximately 800 inhabitants) some $30 \mathrm{~km}$ east of the city of Marseille on a Sainte Beaume Massif. The surroundings of the site were covered by a typical Mediterranean vegetation.

The site during the Athens campaign was located in a suburban background site Thrakomakedones $\left(38^{\circ} 8^{\prime} 37^{\prime \prime} \mathrm{N}\right.$, $23^{\circ} 45^{\prime} 29^{\prime \prime} \mathrm{E}, 550 \mathrm{~m}$ a.s.1.). The site was located approximately $20 \mathrm{~km}$ north from the city of Athens in the foothills of the mountain Parnitha. The site is in the northern edge of the suburban area of the Athens city. The north sector is completely uninhabited and covered with vegetation.

Both the measurement sites were located outside of the cities, so they reflected rural (Marseille) and suburban (Athens) characteristics of aerosol size distributions affected occasionally by local urban pollution.

\subsection{Instrumentation}

Measurements were conducted using similar instruments in order to obtain comparable data. During both of the field campaigns, the aerosol instrumentation was placed in a moving laboratory. The aerosol physical characterization included sub-micron aerosol size distribution measurements with a Differential Mobility Particle Sizer (DMPS, e.g. Aalto et al., 2001) for particles between 3 and $800 \mathrm{~nm}$ in diameter. The DMPS system consisted of two parallel DMPS systems (twin-DMPS) with a closed loop flow arrangement (Jokinen and Mäkelä, 1997). The first system was dedicated to sizes below approximately $50 \mathrm{~nm}$ in diameter. Particles in this range were counted with a TSI-CPC 3025 ultra-fine particle counter. The second system measured the larger particles up to $800 \mathrm{~nm}$ in diameter with a TSI CPC 3010. The time resolution for a full particle size distribution scan was $10 \mathrm{~min}$. The total sub-micron aerosol number concentration was obtained from integrated size distributions. The sampled particles were dried with a Permapure drier prior to size segregation and counting, which ensured that the measurements were conducted for dry particles.

The hygroscopic growth of selected size ambient aerosol particles in sub-saturated conditions were investigated with a Hygroscopic Tandem Differential Mobility Analyzer (HTDMA, Rader and McMurry, 1986; Hämeri et al., 2000). Water uptake was monitored for 10,20 and $50 \mathrm{~nm}$ particles at $88 \pm 3 \%$ relative humidity during the Athens campaign and for 20, 50 and $100 \mathrm{~nm}$ particles during the Marseille 
campaign. The device selected a monodisperse sample from an ambient particle population with a short Vienna type Differential Mobility Analyzer (DMA, Winklmayr et al., 1991). Then a controlled amount of water vapour was added to the sheath flow of the second DMA, which was scanned throught a size spectrum corresponding to a range of 0.9-2.2 times the selected dry sample size. The particles were counted with a TSI model 3010 Condensation Particle Counter. The relative humidities of the sheath and excess flows were monitored with Vaisala HMM-211 relative humidity sensors $( \pm 2 \%$ at $0-100 \%$ ). An additional humidifier was placed in the aerosol flow from the DMA1 to the DMA2 in order to ensure a sufficiently high RH inside the DMA2 and to increase the residence time of particles at elevated water vapour conditions. The aerosol humidifier was controlled to $82 \% \mathrm{RH}$ and monitored with a Vaisala 50 Y-sensor $( \pm 3 \%$ at $0-90 \% \mathrm{RH})$. A Hygro M4 dew point sensor with a chilled mirror sensor (D2) was used as an internal reference for the $\mathrm{RH}( \pm 1.25 \% \mathrm{RH}$ at $95 \%)$.

As the initially dry particles absorb water, their size increases due to water condensation. The increment is a function of particle composition as well as relative humidity $(\mathrm{RH})$ inside the system. Since the RH was kept constant, the changes in particle growth were related to differences in the chemical composition of sampled particles. Typically inorganic salts, such as ammonium sulphate, absorb water vapour in large quantities (e.g. Hämeri et al., 2000), whereas water vapour is condensed to a lesser extent onto organic components (Virkkula et al., 1999; Carrico et al., 2005), excluding some organic acid salts (Peng et al., 2001). The instrument can also detect whether the components are externally or internally mixed within the particle population (Väkevä et al., 2002; Aklilu and Mozurkewich , 2004).

Supporting meteorological and gaseous phase components were measured in the proximity of both measurement sites by local air quality authorities. At Plan d'Aups, the gaseous pollutant levels were monitored at the AIRMARAIX operated air quality stations. Ozone, $\mathrm{NO}_{\mathrm{x}}$ and $\mathrm{SO}_{2}$ concentrations were obtained as one-hour averages. The temperature, relative humidity, and wind velocity and direction were obtained from the closest elevated Meteo France station on a St. Baeume Massif (Le Castellet, $417 \mathrm{~m}$ a.s.1., $10 \mathrm{~km} \mathrm{NE}$ from Plan d'Aups), while the global radiation (i.e. direct and diffuse solar radiation) was from the Aix-en-Provence station. During the Athens campaign, meteorological data (ambient temperature, relative humidity, wind velocity and direction) and air quality data $\left(\mathrm{SO}_{2}, \mathrm{NO}_{\mathrm{x}}\right.$, and $\left.\mathrm{O}_{3}\right)$ were obtained from a measurement station of the Greek Ministry of Environment, Physical Planning and Public Works. The measurements were taken as one-hour averages. They were conducted at Thrakomakedones next to the aerosol measurements presented in this study.
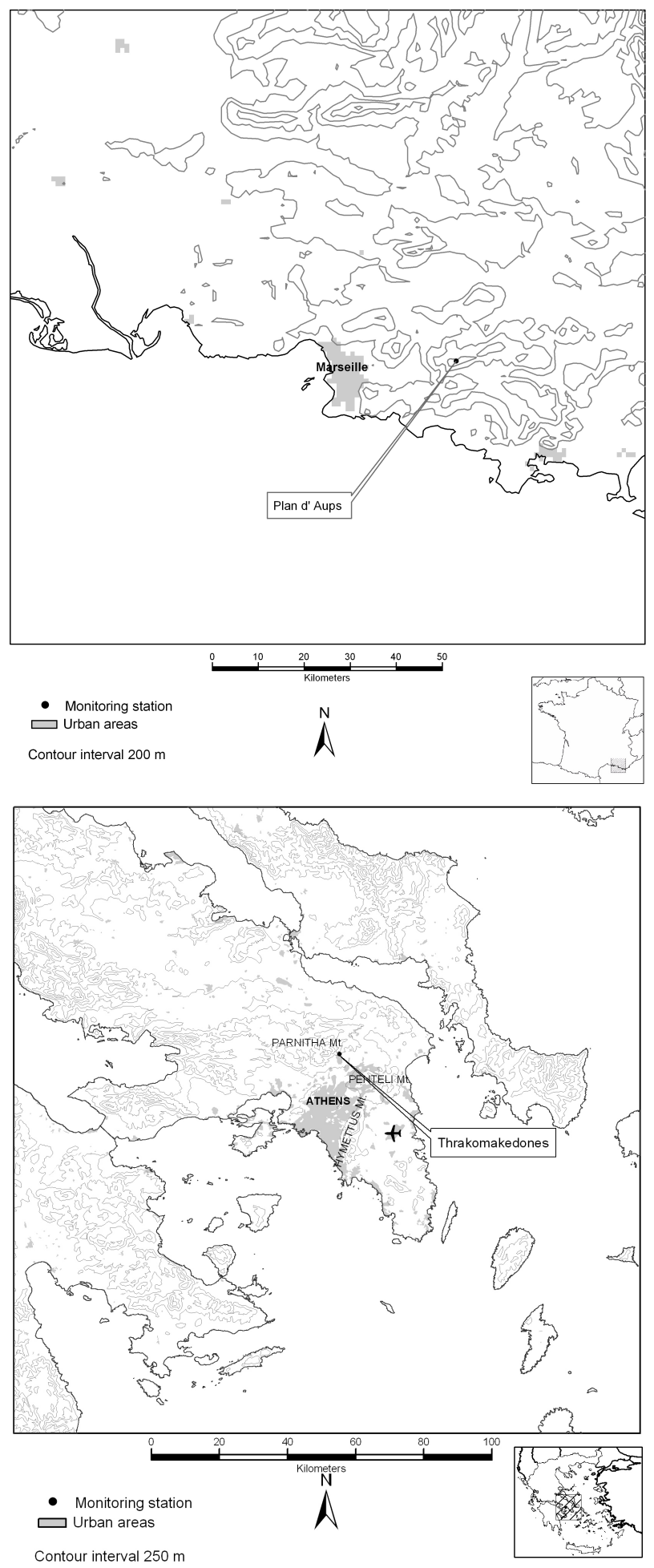

Fig. 1. The area of interest for the BOND-project as well as the two measurement sites at Marseille and Athens. 


\section{Data analysis}

Sub-micron size distributions were inverted from measured mobility spectra by taking into account charging probabilities (Wiedensohler, 1988), counting efficiencies of the condensation particle counters (Mertes et al., 1995; Stolzenburg and McMurry, 1991) as well as transfer functions of the differential mobility analyzers (Stolzenburg, 1988). In addition, the losses in the sampling lines and perma-pure drier were included in the data inversion in the Marseille data set and in the post-processing phase in the Athens data set. The drier induced losses corresponding to laminar flow diffusion losses in a circular tube having a length of $12 \mathrm{~m}$ at $41 \mathrm{~min}^{-1}$ flow rate. Losses were estimated according to Baron and Willeke (2001).

In order to characterize the ambient sub-micron aerosol population in an effective way, log-normal modes (2-3) were fitted to the observed size distributions using an automated and constrained fitting algorithm (Hussein et al., 2005). In order to characterize the observed formation of new atmospheric aerosol particles, methods described in Dal Maso et al. (2005) were utilized. The growth rate (GR) was derived from the rate of change of the geometric mean diameter (GMD) of the fitted nucleation mode. This was done by fitting a first-order polynomial to the fitted GMD during the observed growth time by least squares. The formation rate was determined in a similar manner from the concentration of particles less than $25 \mathrm{~nm}$ in diameter. The obtained rate of change of nucleation mode particle number concentration $\frac{d N_{\text {nuc }}}{d t}$ was corrected for losses caused by coagulation during the analysed period (Dal Maso et al., 2005), so that we obtained the rate of appearance of $>3 \mathrm{~nm}$ particles, $J_{3}$. The vapour concentration responsible for the observed growth and its source rate were calculated based on Kulmala et al. (2001). The effect of pre-existing particle concentration on the newly formed particles was estimated with the aid of condensation sink (CS) presented previously by Kulmala et al. (2001). The growth analysis required a manual selection of data points, which caused uncertainties in the derived results. To estimate this, the analysis was performed multiple times to acquire the variability range of the parameters caused by the method.

The Hygroscopic Tandem Differential Mobility Analyzer (HTDMA) growth factor spectrum was inverted taking into account diffusion broadening the DMA transfer functions (Stolzenburg, 1988). Multiple charging, losses in the sampling lines and the size dependent counting efficiency of the 3010 CPC were not included in the inversion.

Hygroscopic growth factors were examined more closely with the aid of soluble volume fractions (Swietlicki et al., 1999). This construction relies on an assumption that the aerosol volume consists of two parts, one insoluble and one water soluble fraction, which explains all of the observed hygroscopic growth. Ammonium sulphate was used as a model compound representing the soluble volume fraction. The evolution of HTDMA-derived soluble fractions conducted at fixed $10 \mathrm{~nm}$ and $20 \mathrm{~nm}$ particle sizes were linked with the growth of newly formed nucleation mode through the HTDMA size grid. The changes in the soluble volume fraction was interpreted as mass fluxes of water insoluble and soluble material to the nucleation mode using the technique presented in Kulmala et al. (2001).

\section{Results and discussion}

\subsection{General features}

\section{Marseille}

Air quality and meteorological conditions at Plan d'Aups can be affected by both land-sea breeze as well as mountainvalley circulation on a daily basis. An enhanced probability for a pollution episode occurs during the development of the sea-breeze circulation due to local emissions in the Marseille area (Bastin et al., 2005). In addition, Plan d'Aups is occasionally affected by a cold wind called Mistral (Corsmeier et al., 2005). During a prevailing northernly flow, it is channeled by the Alps and Massif Central and accelerated in by the Rhône Valley. Typically this leads to a decrease in pollutant levels. However, during Mistral conditions, Plan d'Aups can be also affected by a long range transport originating from Central Europe (Corsmeier et al., 2005). During BOND campaign, backward trajectory analysis based on HYSPLIT (Draxler and Rolph, 2003; Rolph, 2003) showed that the air masses were arriving to Plan d'Aups continuously from SW direction. The $96 \mathrm{~h}$ backtrajectories started west from the British Isles and then traveled towards northern shores of Spain. Then they passed over the Northern Iberian peninsula and spent the last hours over the Mediterranean Sea before reaching the Plan d'Aups measurement site.

During the measurement campaign the temperature varied at Plan d'Aups between $15^{\circ} \mathrm{C}$ and $25^{\circ} \mathrm{C}$. The days were mostly cloudless as indicated by the global radiation data from Aix-en-Provence (not shown). During 14 to 15 July (DOY 195-196) there were strong rain showers.

Gas-phase pollutant levels obtained from AIRMARAIX monitoring network showed that nitrogen oxide concentration (NOx) at Plan d'Aups was low during the whole campaign indicating only a weak anthropogenic influence. The $\mathrm{NO}_{\mathrm{x}}$ concentration had a day-time average of $1-3 \mathrm{ppb}$, median of $1.1 \mathrm{ppb}$ and occasionally it reached values of $5 \mathrm{ppb}$. Ozone $\left(0_{3}\right)$ concentrations varied from 40 to $80 \mathrm{ppb}$. Average diurnal pattern was that at the night-time average $\mathrm{O}_{3}$ concentration was $47 \mathrm{ppb}$ and during afternoon hours it peaked at $63 \mathrm{ppb}$. Sulphur dioxide $\left(\mathrm{SO}_{2}\right)$ was near the detection limit of the gas analyzer most of the time.

During several days of the campaign, new particle formation via gas-to-particle conversion was observed at Plan d'Aups. The nucleation event days were mostly cloud-free. 

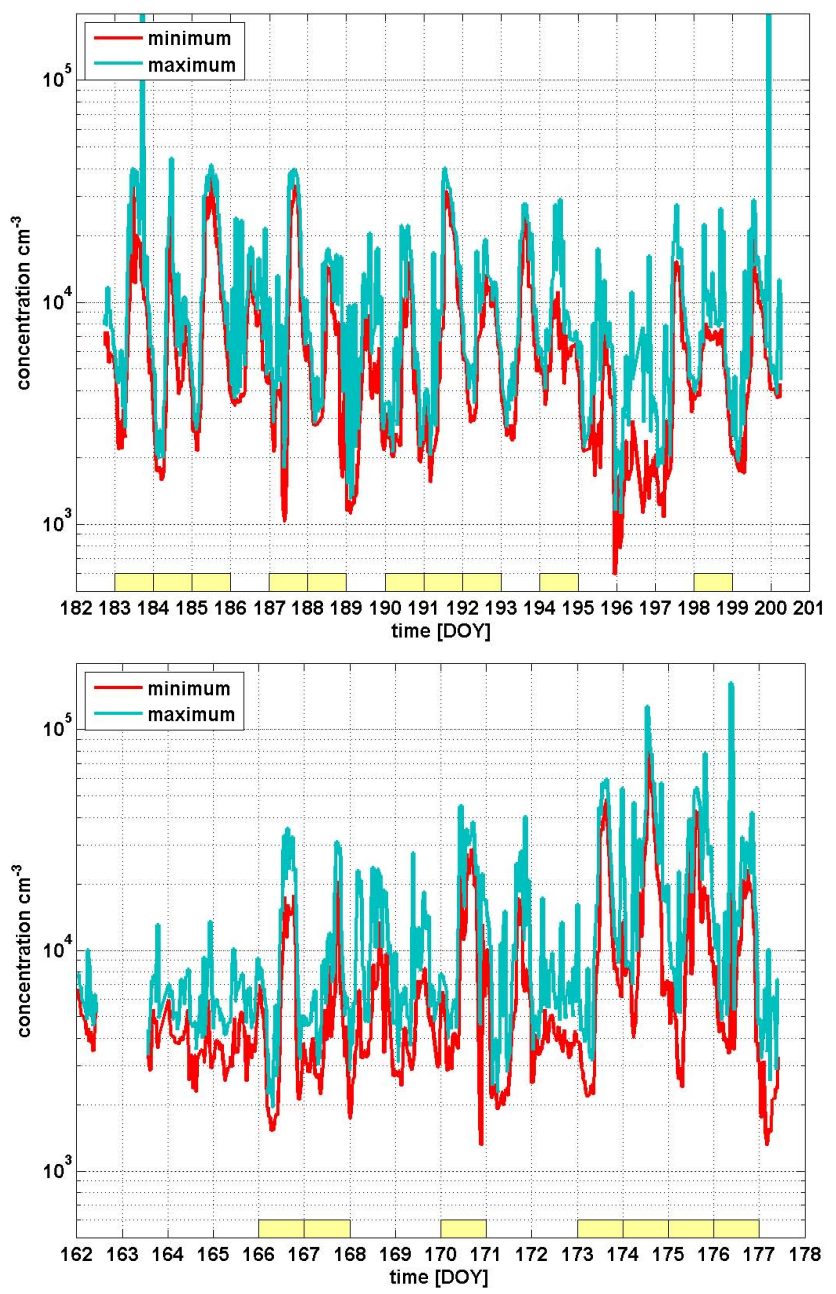

Fig. 2. Average number concentration of sub-micron particles as $1 \mathrm{~h}$ running average observed at Plan d'Aups, Marseille (upper panel) and Thrakomakedones, Athens (lower panel). Yellow bars indicate new particle formation days.

We did not observe any connection with the other local meteorological parameters and the occurrence of the new particle formation. There were no clear connection between the gaseous pollutant concentrations and event days either. Highest levels of $\mathrm{SO}_{2}(15 \mathrm{ppb})$ was observed during one event day. However, two other incidents of elevated $\mathrm{SO}_{2}$ concentrations were not coinciding with an observed secondary aerosol production. In addition, there were also days with considerable aerosol formation but the sulphur dioxide concentrations were below detection limit of the gas analyzer. Thus, the sulphur dioxide was not a limiting factor for the formation of new particles.

The number concentration of sub-micron particles is presented in Fig. 2. The concentration varied around $10^{4} \mathrm{~cm}^{-3}$ as an one-hour average, which is in agreement with earlier total number concentration measurements by Marinoni et al.

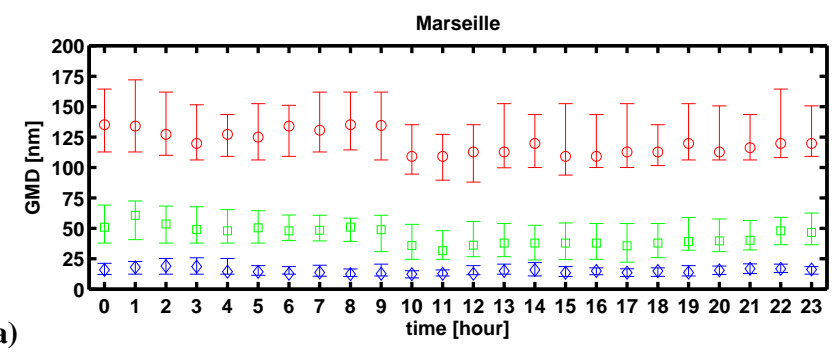

(a)

(b)
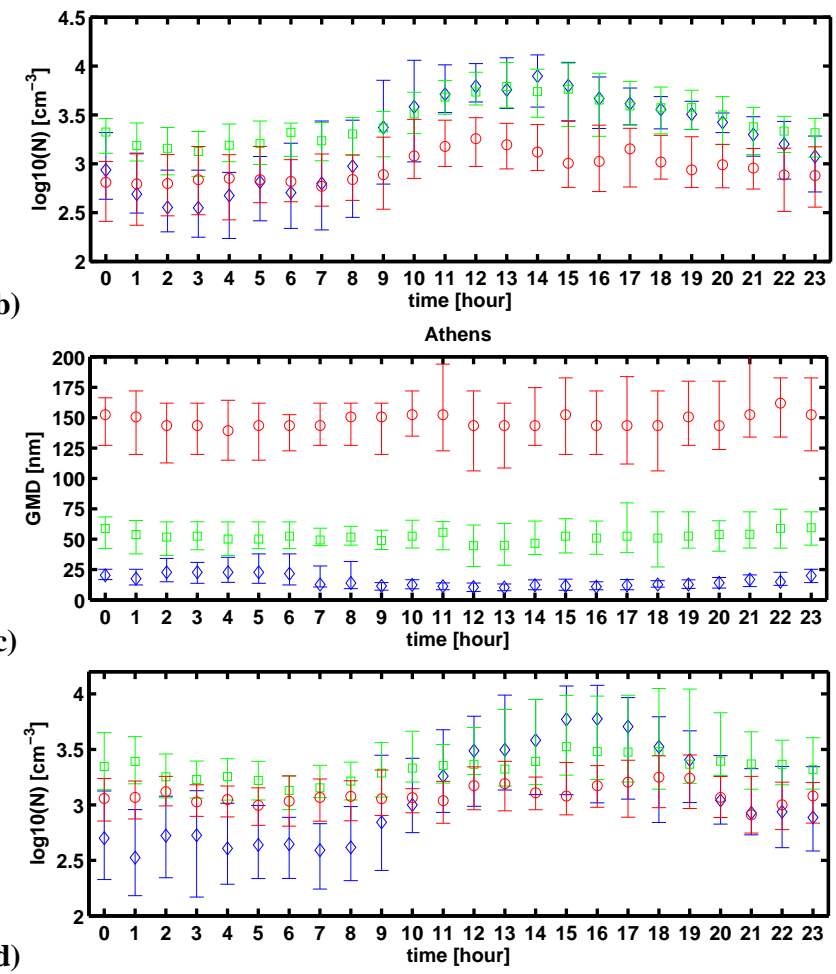

Fig. 3. Diurnal cycle of median geometric mean diameters and mode concentrations at Plan d'Aups, Marseille (a, b) and at Thrakomakedones, Athens (c, d) for nucleation (blue), Aitken (green), and accumulation modes (red). Whiskers in the data points indicate $25 \%$ and $75 \%$ quartiles.

(2005). Until 14 July (DOY 195), the weather was characterized by clear skies. During 14 and 15 July 2002 (DOY 195196) there were strong scattered showers around the measurement site. This was reflected in the total number concentration. The lowest value of $7 \times 10^{2} \mathrm{~cm}^{-3}$ was detected after the rain showers due to rain-out of the particles (Fig. 2).

In order to characterize average size distribution parameters and their diurnal variability at Plan d'Aups site, two to three log-normal distributions were fitted to the observations (Hussein et al., 2005) and average diurnal cycles of the fitted parameters were calculated. A clear diurnal cycle in the fitted total sub-micron aerosol number concentration was observed, as it reached a minimum in early morning hours and then increased by a factor of 6 by early afternoon hours 
Table 1. Median log-normal parameters for sub-micron size range for tri- and bi-modal cases. Bimodal distribution is observed $35.2 \%$ and $22.1 \%$ at Athens and Marseille, respectively. Values in parenthesis represents median absolute deviations.

\begin{tabular}{lccc}
\hline $\begin{array}{l}\text { Marseille } \\
3 \text { modes }\end{array}$ & nucl. & Aitken & acc. \\
$(77.9 \%)$ & & & \\
GMD [nm] & $14(4)$ & $48(12)$ & $127(22)$ \\
GSD & $1.67(0.12)$ & $1.66(0.12)$ & $1.50(0.1)$ \\
$\mathrm{N}\left[\mathrm{cm}^{-3}\right]$ & $2110(1710)$ & $2300(1230)$ & $710(400)$ \\
\hline 2 modes & nucl. & Aitken & acc. \\
$(22.1 \%)$ & & & \\
GMD [nm] & - & $25(9)$ & $83(15)$ \\
GSD & - & $1.73(0.13)$ & $1.70(0.10)$ \\
N $\left[\mathrm{cm}^{-3}\right]$ & - & $3320(1640)$ & $2670(940)$ \\
\hline Athens & & & \\
3 modes & nucl. & Aitken & acc. \\
$(64.8 \%)$ & & & \\
GMD [nm] & $12(5)$ & $53(12)$ & $152(31)$ \\
GSD & $1.55(0.15)$ & $1.67(0.09)$ & $1.65(0.13)$ \\
$\mathrm{N}\left[\mathrm{cm}^{-3}\right]$ & $1560(520)$ & $2150(1000)$ & $1150(1330)$ \\
\hline 2 modes $_{35.2 \%}$ & nucl. & Aitken & acc. \\
GMD [nm] & - & $32(8)$ & $100(15)$ \\
GSD & - & $1.73(0.15)$ & $1.77(0.12)$ \\
N $\left[\mathrm{cm}^{-3}\right]$ & - & $2150(1210)$ & $2220(1000)$ \\
\hline
\end{tabular}

(Fig. 3, lower left panel). Higher particle number concentrations during day-time was also detected by Marinoni et al. (2005) during ESCOMPTE measurement campaign at Plan d'Aups in July 2001. Due to the lack of size resolution below $100 \mathrm{~nm}$ size range, they were not able to connect the concentration increment to a certain particle size range. As seen from the Fig. 3, the concentration enhancement was due to the appearance of aerosol particles below $25 \mathrm{~nm}$ in diameter (nucleation mode particles). Also an increase in the Aitken size range $(25-80 \mathrm{~nm}$ in diameter) particle number concentration as the nucleation mode particles grew to Aitken size during the afternoon hours and by regional direct emissions. There was no diurnal cycle in the fitted accumulation mode particle number concentration.

Average modal diameters varied from 20 to $30 \mathrm{~nm}$ and 50 to $75 \mathrm{~nm}$ for the nucleation and Aitken mode, respectively (Fig. 3, upper left panel.). The modal diameters were smaller during day-time than during night-time. Modal diameter increased towards the evening due to condensational growth of the particles. A stable accumulation mode was detected at $120-140 \mathrm{~nm}$ throughout the day. The accumulation mode particle concentrations increased only slightly during the day. The increase in the number concentration of nucleation mode particles can be a result of e.g. direct traffic emissions or due to formation of new particles from gaseous precursors. These two processes can be distinguished from each other by studying the size distribution evolution more closely. This is addressed in Sect. 4.2.

Median modal parameters during the campaign are presented in Table 1. During the BOND field campaign, the HYSPLIT backtrajectories indicated that the air masses were of Atlantic origin and passed the Pyrenees prior to arriving at the Mediterranean area. Van Dingenen et al. (2005) classified air mass trajectories for MINATROC campaign at Monte Cimone, Northern Italy. Comparing Van Dingenen et al. (2005) Western Europe (W-EUR) and Mediterranean (MED) trajectory classes with our results yielded similar submicron number concentration values of $2-3 \times 10^{3} \mathrm{~cm}^{-3}$. At Plan d'Aups, the median modal diameters of the accumulation mode were smaller than observed by Van Dingenen et al. (2005) at Monte Cimone for W-EUR and MED -trajectory classes. The Aitken mode at Monte Cimone was within the median deviation of the BOND data. Van Dingenen et al. (2005) did not specify the (aged) nucleation mode separately. In addition, the Plan d'Aups distribution data was not divided into trajectory classes but a grand average of three weeks of measurements were reported.

A histogram of fitted mode diameters and concentrations is depicted in Fig. 4. At Plan d'Aups, accumulation mode concentration strongly decreased as the modal diameter (GMD) increased. Typical concentrations varied from roughly a few hundreds to two thousand particles $\mathrm{cm}^{-3}$ as GMD varied from 100 to $200 \mathrm{~nm}$. Typical Aitken mode concentrations were from $2 \times 10^{3}$ up to $2 \times 10^{4} \mathrm{~cm}^{-3}$. A similar concentration range was typical also for nucleation mode particles. This indicates that the formation of new particles and subsequent growth was dominated by condensation, which is a concentration preserving process.

\section{Athens}

The Athens field campaign was characterized by two clearly different time periods with respect to air quality. During the first period (11 to 23 June 2003, DOY 162 to 174, excluding 19 June, DOY 170), the air quality at the Thrakomakedones measurement site was dominated by long range-transport of pollutants whereas the latter part of the campaign (19 June and 24 to 25 June, 2003, DOY 170 and DOY 175 to 176) was strongly affected by local photochemical pollution from the urban surroundings.

The local temperature varied from a minimum of $18^{\circ} \mathrm{C}$ to $32^{\circ} \mathrm{C}$. The ground level relative humidity remained below $70 \%$ at all times. Between 11 and 21 June 2003 (DOY 162 to DOY 172), synoptic winds from the north were dominating the large scale flow patterns in the Athens area. According to back-trajectory analysis using the HYSPLIT transport and dispersion model (Draxler and Rolph, 2003; Rolph, 2003), the air masses circulated over Eastern Europe and arrived at the sampling site via the Black Sea and Borpor's Strait. The local wind direction was predominantly from the North and 

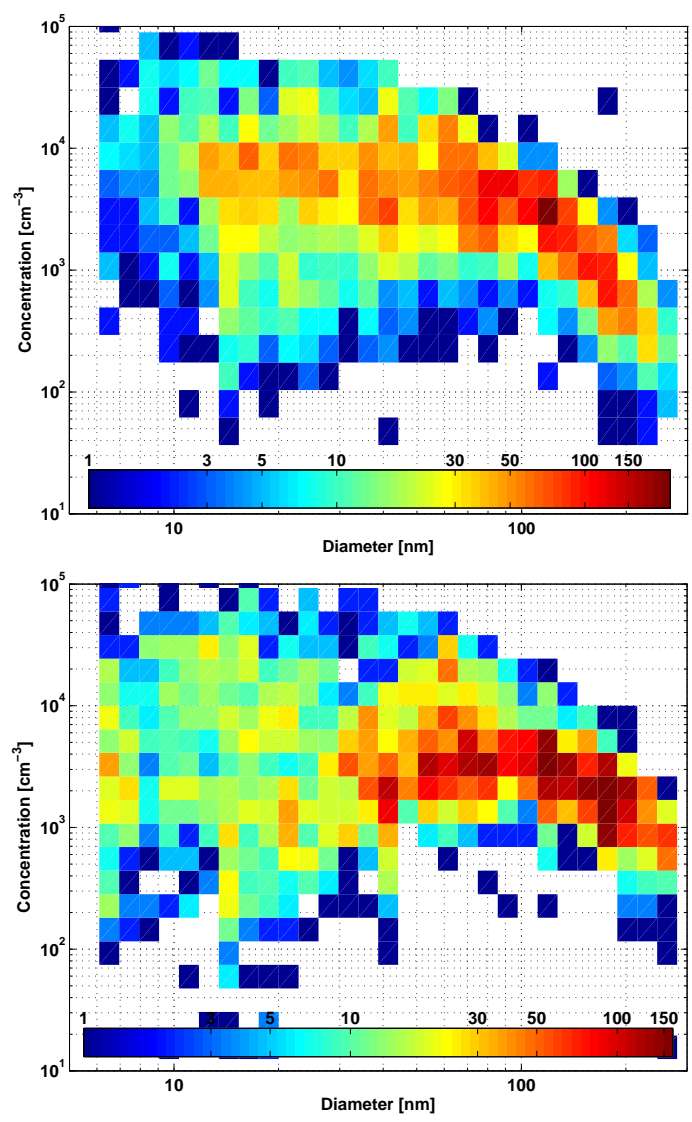

Fig. 4. A histogram plot of fitted modal concentrations as a function of geometric mean diameters for Marseille (top) and Athens (bottom) field campaigns. Red colors indicate larger frequency of observations at a certain size bin. A persistent accumulation mode at $100-200 \mathrm{~nm}$ is present at both sites. Aitken mode $(20-80 \mathrm{~nm})$ was, on average, slightly larger at Marseille. Nucleation mode $(<20 \mathrm{~nm})$ concentration and size are more variable in Athens.

the velocity between 5 to $10 \mathrm{~m} \mathrm{~s}^{-1}$ during days 162 to 168 and decreased to $1-8 \mathrm{~m} \mathrm{~s}^{-1}$ for the next six days but the wind was still from the North.

During this time period, the Thrakomakedones site was relatively unaffected by the strongly variable local urban particulate sources. This is indicated by low $\mathrm{NO}_{\mathrm{x}}$ concentrations as measured by the Greek Ministry of Environment. During this period, the median of one-hour averaged $\mathrm{NO}_{\mathrm{x}}$ concentration and ozone were $8 \mathrm{ppb}$ and $108 \mathrm{ppb}$, respectively. The one-hour average total sub-micron particle number concentration was typically in the range of 2000-20000 particles $\mathrm{cm}^{-3}$ (Fig. 2). The highest concentrations were observed during new particle formation episodes, which are examined in more detail in Sect. 4.2.

The last campaign days were characterized by relatively low local winds from variable directions. This was reflected in increase in both ozone and nitrous dioxide concentrations.
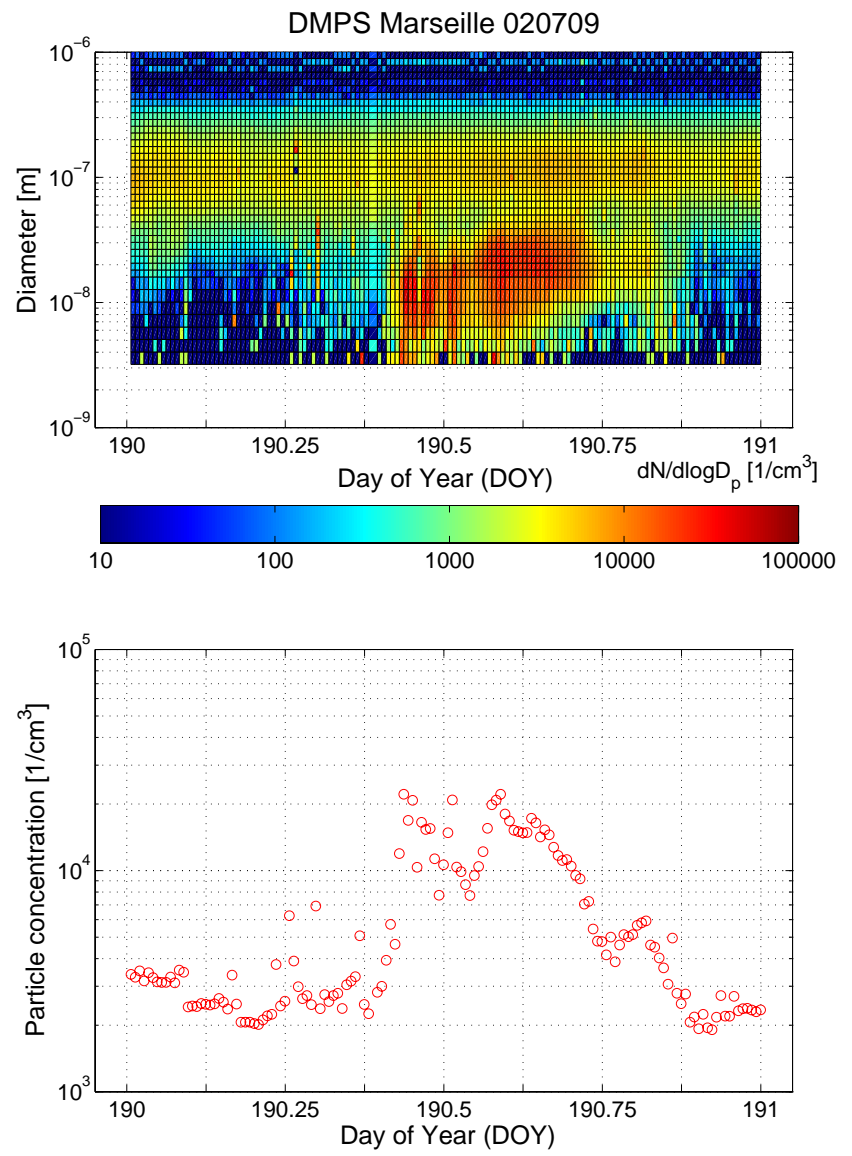

Fig. 5. A selected particle formation event day during Marseille field campaign (9 July 2002). The formation was detected at about 10:00 (upper panel). Total number concentration increased by an order of magnitude as the sub- $10 \mathrm{~nm}$ particles entered the measurement range of the instrument. Subsequently particles grew to Aitken mode.

The median one-hour-average $\mathrm{NO}_{\mathrm{x}}$ and $\mathrm{O}_{3}$ concentrations were 14 and $111 \mathrm{ppb}$, respectively. One-hour average ozone levels reached as high as $200 \mathrm{ppb}$ and $\mathrm{NO}_{\mathrm{x}}$ maximum was $60 \mathrm{ppb}$.

The urban influence was also reflected to the observed submicron particle number concentrations. On average, the onehour sub-micron particle number concentration increased to $1 \times 10^{4} \mathrm{~cm}^{-3}$. The concentration also fluctuated more than during the clean period, ranging from a few thousands up to $10^{5}$ particles $\mathrm{cm}^{-3}$ during the polluted period. This is due to the higher variability of the urban particulate pollution sources (e.g. traffic and industry). The location of the measurement site in the northern rim of the urban area also enables the flow of cleaner air from the surrounding rural areas as well as polluted air from urban areas. Occasionally the urban plume reached the observation site and subsequently the sub-micron particle number concentrations increased up to $10^{5} \mathrm{~cm}^{-3}$ as one hour average concentration. Flocas et al. 

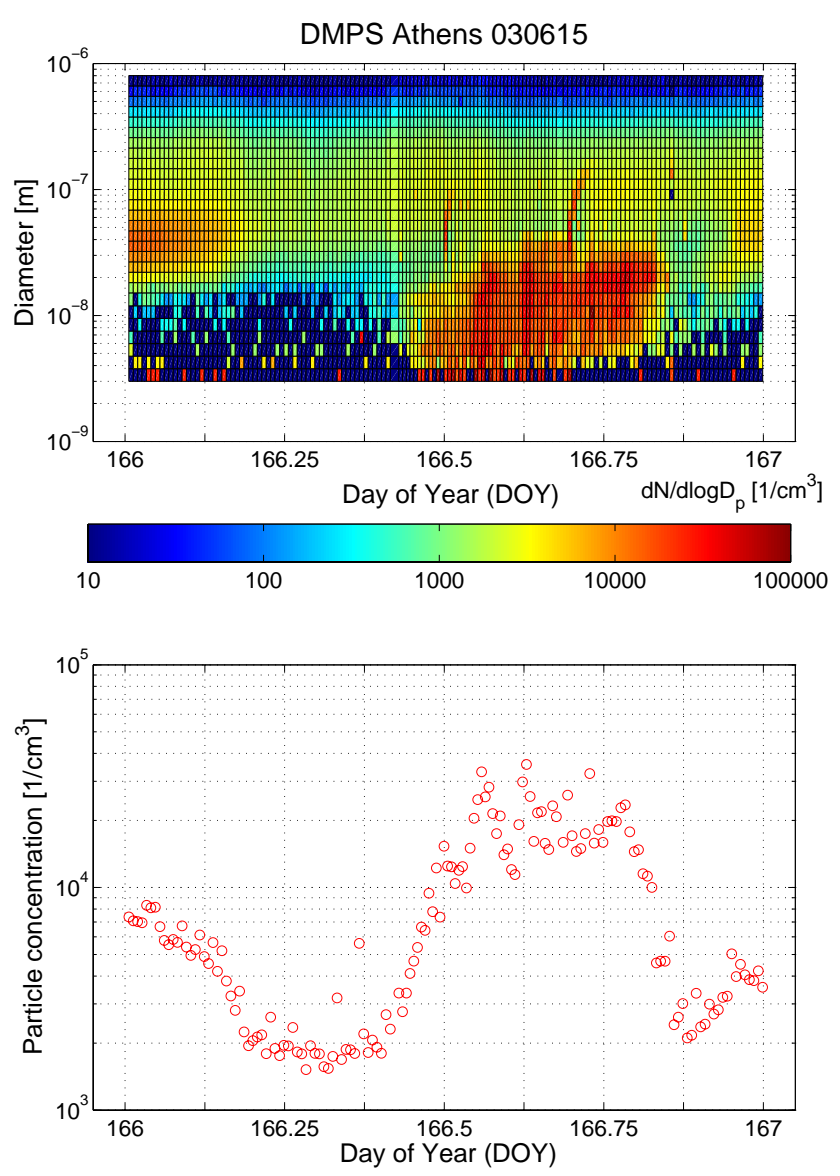

Fig. 6. A selected particle formation event day during Athens field campaign (15 June 2003). The formation was detected at about 10:00 (upper panel). Total number concentration increased by an order of magnitude as the sub-10 $\mathrm{nm}$ particles entered the measurement range of the instrument. Subsequently particles grew to Aitken mode.

(2006) performed airborne number concentration measurements in the Greater Athens Area and reported, on average, one order of magnitude higher sub-micron particle number concentration aloft of the urban populated Athens. This indicates that the Thrakomakedones sampling site in this study represents the background concentrations in the Athens Area even during a polluted period in terms of particle number concentrations.

Two to three log-normal distributions were fitted to the size distribution observations. The diurnal variability of the fitted parameters are presented in Fig. 3. A histogram of all the fitted mode diameters and concentrations is depicted in Fig. 4. Average modal parameters during the campaigns are presented in Table 1.

The diurnal variation of accumulation mode $\left(D_{p}>80 \mathrm{~nm}\right)$, Aitken $\left(\mathrm{D}_{p} 25-80 \mathrm{~nm}\right)$ and nucleation mode $\left(\mathrm{D}_{p}<25 \mathrm{~nm}\right)$ geometric mean diameters (GMD) and number concentrations at Thrakomakedones, Athens, are presented in Fig. 3. The
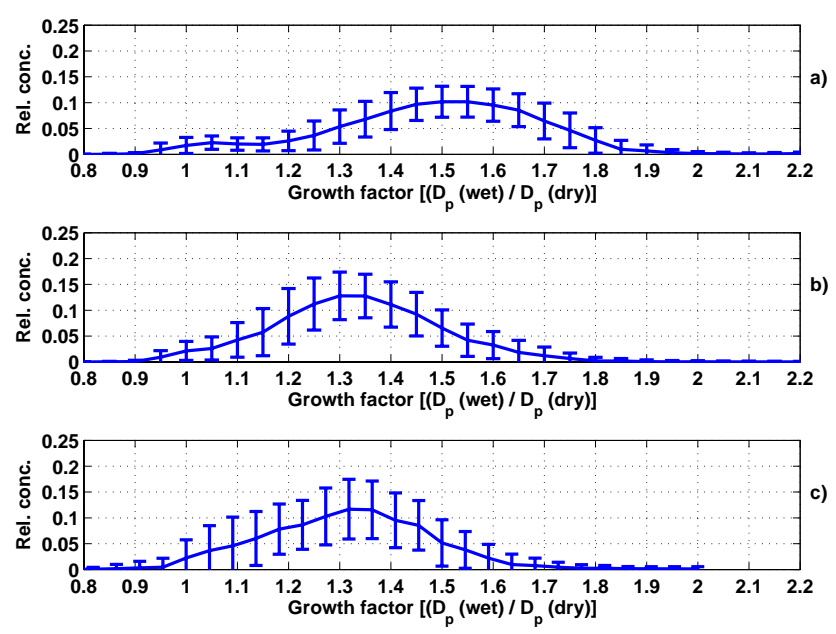

Fig. 7. Normalized median growth spectrum for (a) $100 \mathrm{~nm}$, (b) $50 \mathrm{~nm}$, and (c) $20 \mathrm{~nm}$ particles at $88 \% \mathrm{RH}$ during Plan d'Aups, Marseille field campaign. Errorbars are mean absolute deviations.
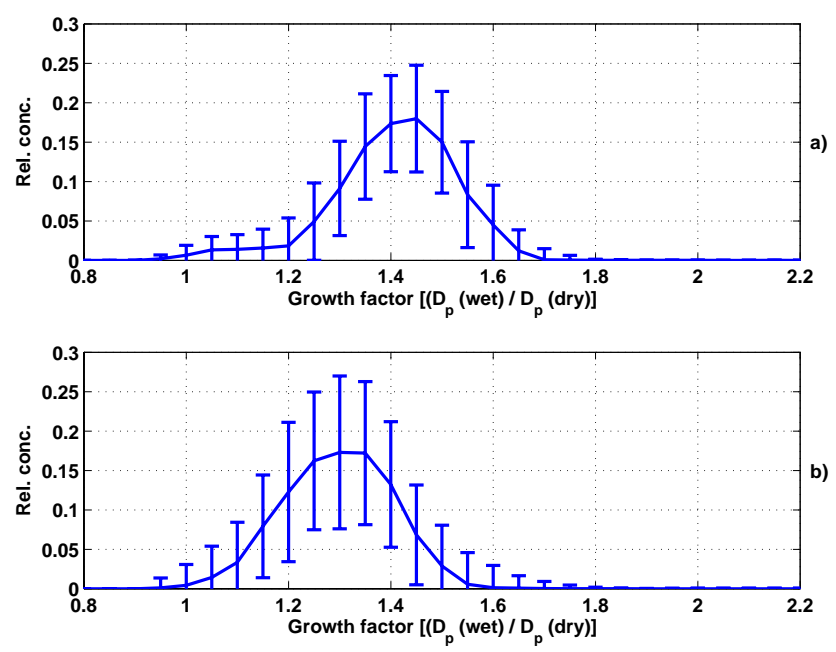

Fig. 8. Normalized median growth spectrum for (a) $50 \mathrm{~nm}$, and (b) $20 \mathrm{~nm}$ particles at $88 \% \mathrm{RH}$ during Thrakomakedones, Athens field campaign. Errorbars are mean absolute deviations.

number concentration increment during daylight hours was due to the appearance of the nucleation mode into the size spectrum with a concentration comparable to that in the Aitken mode. Average fitted GMDs for Aitken and accumulation modes remained relatively constant throughout the day at 50 and $150 \mathrm{~nm}$, respectively. The average nucleation mode diameter decreased before the midday to $10 \mathrm{~nm}$ and during the evening it grew to $25 \mathrm{~nm}$ in size.

The fitted particle number concentrations in each mode showed a maximum during day-time. An increase in the total number concentration during the daylight hours was explained by a sharp and moderate increase in the particle number concentration in the nucleation mode and Aitken mode, 
respectively. The accumulation mode number concentration remained quite constant throughout the day at $1 \times 10^{3} \mathrm{~cm}^{-3}$. This behaviour is due to photochemical secondary aerosol production via gas-to-particle conversion followed by growth to the Aitken sizes as well as direct emissions of nucleation and Aitken mode particles from anthropogenic activities. The two pathways cannot be distinguished from each other just by looking at the variation of the total number concentration, but they can be separated by a careful examination of the size distribution evolution during the day. This will be done in the Sect. 4.2.

Since the Athens site was located at the northern edge of the city, the local wind direction had a strong effect on both total sub-micron particle number concentration and lognormal size distribution parameters. This indicated dramatic differences in aerosol populations residing over the city (southern sector) and over the surrounding unpopulated area (northern sector). The urban aerosol consisted of larger amount of Aitken size particles ( $\mathrm{Dp}=30-80 \mathrm{~nm})$ as compared with the cleaner background air. The dominating wind direction was north during the Athens campaign (not shown). This resulted in lower grand-average sub-micron aerosol particle concentrations than was expected to reside in Thrakomakedones based on the proximity of polluted urban areas. Due to this, these results do not represent the average character of ambient aerosol populations in Athens city areas, but the mean parameters of sub-micron particles in sub-urban Greece, which is occasionally affected by pollution from the city areas.

The diurnal evolution of modal number concentrations are similar between Athens and Marseille (Fig. 3). At both sites the concentration increment is due to Aitken and nucleation mode particles. In Athens, the accumulation mode is slightly larger $(\mathrm{GMD}=152 \mathrm{~nm})$ in size than in Marseille $(\mathrm{GMD}=127$, Table 1). At both sites, bimodal size distributions were dominantly observed during the night-time, when photochemical production of new particles was inhibited.

The most striking difference between the histograms of the fitted GMDs and modal concentrations (Fig. 4.) was in the size range below $30 \mathrm{~nm}$. At Plan d'Aups, Marseille, the nucleation mode and Aitken mode were connected, showing a consistent growth to larger sizes. At Thrakomakedones, Athens, the transition from the nucleation mode to the larger Aitken mode was more discrete. This was most probably due to a primary production of Aitken and nucleation mode particles, which were not growing steadily in the vicinity of the measurement site.

\subsubsection{Average hygroscopic properties}

\section{Marseille}

The median hygroscopic growth factor (GF) spectra for $100 \mathrm{~nm}, 50 \mathrm{~nm}$ and $20 \mathrm{~nm}$ particles are presented in Fig. 7. Accumulation mode particles were typically externally mixed. Based on the median growth factor spectrum, $8 \%$ of the particles had GF less than 1.15, whereas most of the particles (90\%) were more hygroscopic (peak GF at 1.5). This is in agreement with hygroscopicity measurements of Van Dingenen et al. (2005) at Monte Cimone, Italy. They observed less a hygroscopic mode in $10 \%$ of the time at the $100 \mathrm{~nm}$ particle size when the origin of the air mass was from the Atlantic Ocean.

A pronounced more hygroscopic mode indicates a large contribution of water soluble components in the $100 \mathrm{~nm}$ particle size. According to Marinoni et al. (2005), the submicron particle chemical composition at Plan d'Aups during ESCOMPTE campaign in summer 2001 was governed by sulphate and ammonia $(68 \pm 30 \%$ and $20 \pm 9 \%$ of the inorganic mass, $45 \%$ and $13 \%$ of average fine aerosol mass). However, the absolute values for observed growth factors indicate that the $100 \mathrm{~nm}$ particles were not solely composed of inorganic water-soluble compounds. The observed growth factors were interpreted with the aid of soluble fraction (Swietlicki et al., 1999). For $100 \mathrm{~nm}$ particles at Plan d'Aups, the average soluble volume fraction of the more hygroscopic mode was 0.75 i.e. as a volume fraction, $75 \%$ of ammonium sulphate would explain the observed hygroscopic growth of this mode. This indirectly estimated composition is in a reasonable agreement with $61 \%$ average soluble inorganic mass obtained by Marinoni et al. (2005).

The insoluble volume fraction of the more hygroscopic mode, on the other hand, was $25 \%$ based on HTDMA data. By adding organic matter (12.4\%), black carbon (10.8\%), organic acids $(3.4 \%)$ and dust $(11 \%)$ mass fractions from average fine aerosol composition by Marinoni et al. (2005) together, we get an estimate of $37.6 \%$ for water-insoluble material. This is consistent, considering the assumption in the TDMA data interpretation, as well as the fact that $100 \mathrm{~nm}$ particles sampled with the TDMA setup do not necessarily represent similar composition as the larger particles, which dominate the mass of the particles and thus count more in the chemical analysis.

For Aitken mode particles $(50 \mathrm{~nm}$, Fig. $7 \mathrm{~b})$ the median growth factor spectrum was dominated by one mode at $\mathrm{GF}=1.30$. The particles having GF less than 1.1 contributed $7 \%$ and particles with GF more than 1.55 only $8 \%$ to the total number of sampled particles. Van Dingenen et al. (2005) detected a less hygroscopic mode to occur $6 \%$ of the time for $50 \mathrm{~nm}$ particles at Monte Cimone, Italy. According to our results, the average soluble fraction for $50 \mathrm{~nm}$ particles was $42 \%$. This indicates a larger volume fraction of water insoluble components in the Aitken mode compared with the accumulation mode.

The hygroscopicity of nucleation mode particles had the largest variability (Fig. 7c). The growth spectrum had a maximum at $\mathrm{GF}=1.3$, which corresponds to an average soluble fraction of $66 \%$. The variability in the GF indicates indirectly that the chemical composition varied as well. Most of these particles were probably formed from gaseous precursors or 
by direct emissions. Their sizes are further increased by condensation of both inorganic and organic condensable vapors. The variability in precursors and ratio between soluble and insoluble precursors (organic/sulphuric acid) results in the observed variability in the nucleation mode growth factor changes.

\section{Athens}

The median hygroscopic growth factor spectrum is depicted in Fig. 8 for $50 \mathrm{~nm}$ and $20 \mathrm{~nm}$ particles. Aitken particles had a bi-modal growth distribution at almost all times. On average, $10 \%$ of $50 \mathrm{~nm}$ particles were less hygroscopic or even hydrophobic and the remaining fraction of particles belonged to a more hygroscopic class. The average growth factor of 1.45 corresponds to a soluble fraction of $75 \%$, which is higher than the GF of $50 \mathrm{~nm}$ particles in Plan d'Aups but similar to the GF of $100 \mathrm{~nm}$ particles Plan d'Aups.

The water uptake of nucleation mode particles (Fig. 8, bottom panel) was, on average, smaller in Thrakomakedones than at Plan d'Aups and the growth was less variable. This indicates indirectly that the chemical composition of $20 \mathrm{~nm}$ particles at Thrakomakedones varies less than in Plan d'Aups. The hydrophobic mode at this size seems to be nonexistent, when looking at the grand-average growth spectrum.

During the Athens field campaign, also $10 \mathrm{~nm}$ particle water uptake was monitored. The number concentration at this size was most of the time too close to the detection limit of the TDMA setup and thus the grand-average GF spectrum over the whole campaign provided no useful information.

\subsection{Formation, growth and hygroscopicity}

\subsubsection{Aerosol formation events}

As indicated by the diurnal cycle of nucleation mode particle concentrations, the formation and subsequent growth can be observed often in Athens and Marseille. As an example, the evolution of the size distribution during two formation events are presented in Figs. 5 and 6 for Plan d'Aups and Thrakomakedones, respectively. In the morning hours, a mode below $10 \mathrm{~nm}$ in diameter was observed. The total number concentration increased by a factor of 10 . During the day, the size of the mode increased to approximately $30 \mathrm{~nm}$. In both cases, the nucleation mode disappears in the evening. This is probably due to relatively rapid growth of the formed particles and the elevated location of the measurement sites. As the boundary layer mixing relaxes during the evening, the site remains in a more stagnant nocturnal residual layer instead of the mixed layer.

At Marseille, 10 days with new particle formation events were observed and there were 10 days without an event. Corresponding numbers for Athens campaign were 7 and 11, respectively. This indicates that the event frequency is above
$30 \%$ in this specific rural Mediterranean area in summertime. This result is in agreement with the recent findings by Laaksonen et al. (2005) in Po Valley, Italy.

\subsubsection{Formation and growth characteristics}

A total of 7 new particle formation events occurred during the Thrakomakedones field campaign. At Plan d'Aups, Marseille, four new particle formation event days were clear enough to be analyzed with a method presented by Dal Maso et al. (2005). In addition, six other days during the Marseille field campaign were identified as possible new particle formation days. Calculated formation rates $\left(J_{3}\right)$ and subsequent growth rates (GR) of the nucleation mode particles are presented in Table 2 . The growth rates were $2-8 \mathrm{~nm} \mathrm{~h}^{-1}$ at Plan d'Aups and 1.2-9.9 $\mathrm{nm} \mathrm{h}^{-1}$ at Thrakomakedones. The formation rates were in the range $3-5.3 \mathrm{~cm}^{-3} \mathrm{~s}^{-1}$ at Plan d'Aups and in the range $1.3-6.5 \mathrm{~cm}^{-3} \mathrm{~s}^{-1}$ at Thrakomakedones. These values are in agreement with recent observations in rural/suburban areas (Kulmala et al., 2004b).

At Thrakomakedones the highest growth rates were observed during the polluted period (19 June and 23 June to 25 June, marked as $\mathrm{P}$ in Table 2) of the campaign. The polluted period was also apparent due to higher condensation sink values as compared with the clean period, during which the strong north winds de-coupled the site from the urban surroundings. During the polluted period the enhanced sink was, however, not able to hinder new particle formation from taking place. As the sink increases, coagulation scavenging of nucleation mode by the pre-existing population starts to be a significant sink to the newly formed particles. Consequently, they must grow or form faster in order to survive and their appearance can be classified as an event based on size distribution evolution (Kulmala et al., 2005).

The source rate of condensable vapor (Table 2) in both areas seems to be significantly higher than in rural areas like Hyytiälä, Southern Finland. During polluted events at Thrakomakedones, the source rate was approximately double compared with the clean events. This is still one order of magnitude smaller than in New Delhi (Mönkkönen et al., 2005).

\subsection{Processes related to aerosol formation}

According to our results the nucleation events are related to non-cloudy days showing that solar radiation is needed. The driving force for new particle formation could be sulphuric acid and the growth can be related to both sulphuric acid and organic vapours (e.g. Kulmala, 2003). A high condensation sink can also hinder new particle formation.

The role of sulphuric acid to new particle formation at Plan d'Aups site was studied with the aid of proxy data. The product of sulphur dioxide and global radiation was used as an indicator of sulphuric acid production rate in the atmosphere whereas the pre-existing particle condensation sink 
Table 2. Calculated formation (J3) and growth rates (GR) of nucleation mode particles during selected new particle formation event days during BOND campaigns in Athens and Marseille. At Plan d'Aups, Marseille, the formation characteristics could be extracted from size distribution evolution only for four out of ten event days. Condensation sink (CS) provided by the pre-existing particle population to the condensable vapour is tabulated. Estimations of the condensable vapour concentrations $\left(\mathrm{C}_{\mathrm{vap}}\right)$ responsible for the observed growth at steady state as well as its source rate $(\mathrm{Q})$ are presented in the table. The values in parentheses represent uncertainties of the derived parameters.

\begin{tabular}{lllllll}
\hline Date & $\begin{array}{l}\text { Day of Year } \\
\text { DOY }\end{array}$ & $\begin{array}{l}\mathrm{GR} \\
{\left[\mathrm{nmh}^{-1}\right]}\end{array}$ & $\begin{array}{l}\mathrm{J3} \\
{\left[\mathrm{cm}^{-3} \mathrm{~s}-1\right]}\end{array}$ & $\begin{array}{l}\mathrm{CS} \\
{\left[10^{-3} \mathrm{~s}^{-1}\right]}\end{array}$ & $\begin{array}{l}\mathrm{C}_{\mathrm{vap}} \\
{\left[10^{7} \mathrm{~cm}^{-3}\right]}\end{array}$ & $\begin{array}{l}\mathrm{Q} \\
{\left[10^{5} \mathrm{~cm}^{-3} \mathrm{~s}^{-1}\right]}\end{array}$ \\
\hline $\begin{array}{l}\text { Marseille } \\
\text { 2 July 2002 }\end{array}$ & 183 & $2(0.1)$ & $5.3(0.1)$ & $7.9(1)$ & $2.8(0.1)$ & $2.2(0.2)$ \\
3 July 2002 & 184 & $8(2)$ & $5.3(0.1)$ & $9.1(3.7)$ & $11.0(3)$ & $10(1.5)$ \\
4 July 2002 & 185 & n.a. & n.a. & n.a. & n.a. & n.a. \\
6 July 2002 & 187 & $4.5(1)$ & $3(0.5)$ & $8.1(4.2)$ & $6.2(1.4)$ & $5(1.5)$ \\
7 July 2002 & 188 & n.a. & n.a. & n.a. & n.a. & n.a. \\
9 July 2002 & 190 & $2.6(0.3)$ & $3(1.8)$ & $7.5(2)$ & $3.6(0.4)$ & $2.7(0.4)$ \\
10 July 2002 & 191 & n.a. & n.a. & n.a. & n.a. & n.a. \\
11 July 2002 & 192 & n.a. & n.a. & n.a. & n.a. & n.a. \\
13 July 2002 & 194 & n.a. & n.a. & n.a. & n.a. & n.a. \\
17 July 2002 & 198 & n.a. & n.a. & n.a. & n.a. & n.a. \\
\hline Athens & & & & & & \\
15 June 2003 & 166 & $1.2(0.2)$ & $2.5(0.5)$ & $4.8(2.7)$ & $1.7(0.3)$ & $0.8(0.3)$ \\
16 June 2003 & 167 & $1.3(0.3)$ & $1.3(0.5)$ & $10.0(4.6)$ & $1.8(0.4)$ & $1.8(0.4)$ \\
(P) 19 June 2003 & 170 & $9.9(0.4)$ & $5.05(0.7)$ & $10.6(1.7)$ & $13.7(0.5)$ & $14.5(1.8)$ \\
22 June 2003 & 173 & $4.6(0.2)$ & $2.2(0.4)$ & $11.0(2.1)$ & $6.3(0.3)$ & $7(1)$ \\
(P) 23 June 2003 & 174 & $4.1(0.2)$ & $6(0.8)$ & $23(5)$ & $5.6(0.3)$ & $13(2)$ \\
(P) 24 June 2003 & 175 & $7(1.5)$ & $6.5(1.5)$ & $15(6)$ & $9.7(2.1)$ & $14(3)$ \\
(P) 25 June 2003 & 176 & $1.3(0.3)$ & $1.4(0.4)$ & $17(7)$ & $1.8(0.5)$ & $3(0.5)$ \\
\hline
\end{tabular}

(CS) surface was an estimate for the loss rate of sulphuric acid. The ratio between the source and loss rates was slightly higher during event days than during non-event days. This gives some support for the hypothesis that sulphuric acid plays a key role in the atmospheric nucleation at least during some events. Unfortunately, the Marseille data set is too short to investigate on the relative contribution of sulphuric acid to the growth. In addition, we cannot compare these results with Athens data, since there were no sulphur dioxide observations during that campaign.

\subsubsection{Hygroscopicity during events}

Sulphuric acid (SA) itself is not typically able to explain the condensation growth of nucleation mode particles (Kulmala et al., 2004a). Under polluted conditions in Atlanta, USA, Stolzenburg et al. (2005) showed that sulphuric acid explained all the observed growth, whereas in rural Finland SA explained only $10 \%$ of the growth of newly formed particles according to Boy et al. (2005). The rest of the growth was attributed to condensation of various organic compounds (Boy et al., 2005). Particles containing sulphuric acid are hygroscopic, whereas organics in the particulate phase are typically less hygroscopic (Virkkula et al., 1999). These differences in the water vapour affinities and changes in hygroscopic growth during the events will give insight to mass fluxes of sulphuric acid and organics and their ratio during the growth of the new particles. During growth the geometric mean diameter of the nucleation mode coincides with different HTDMA dry sizes at different times. Thus, one is able to interpret the measured GF changes as differences in the mass fluxes to the nucleation mode particles.

\section{Marseille}

The measurement days were divided into days with new particle formation (event day) and days without detectable secondary aerosol production. The median day-time variation during event and non-event days of median hygroscopic growth factor spectrum for the classified data is presented in Fig. 9 for 100,50 and $20 \mathrm{~nm}$ particles. Since the production of secondary particles was observed to take place during day-light hours, the daytime median spectrum is presented. For the daytime variation, only data points with more than 3 contributing days were considered. Since several days were averaged, these results represent an average behaviour of hygroscopicity during events at Plan d'Aups.

The hygroscopicity of initially dry $100 \mathrm{~nm}$ particles was, on average, larger than that of Aitken and nucleation mode particles during both non-events and event days. This is due to an increased curvature of the smaller particles (Kelvin effect), making their water vapour affinity lower. This leads to 
lower growth factors (GF) for smaller particles, if the composition remains the same as for accumulation and Aitken mode particles.

The hygroscopicity of $100 \mathrm{~nm}$ particles during event days increased from 1.4 to 1.6 during the afternoon hours (Fig. 9). A similar tendency was observed also in Aitken mode $(50 \mathrm{~nm})$ hygroscopicity as well as to a smaller extent also in nucleation mode $(20 \mathrm{~nm})$ particles. The nucleation mode GF had a maximum of 1.6 at 10:00 during event days. There was no peak in the GF of $50 \mathrm{~nm}$ particles during morning hours but it steadily decreased towards the minimum of 1.3 in the afternoon (15:00 LT).

The particles formed from gaseous precursors during the morning hours grew subsequently to larger sizes. The $20 \mathrm{~nm}$ particles had a maximum GF during the early stage of the nucleation mode growth. This indicates that the growth was dominated by more hygroscopic compounds during the morning hours. During the afternoon the GF of $20 \mathrm{~nm}$ particles decreased at the same time as the nucleation mode grew to larger sizes. This is corroborated with a decrease of water uptake of $50 \mathrm{~nm}$ particles during the afternoon hours. Later in the afternoon the hygroscopicity increased during the event days again.

During the non-event days, the hygroscopicity tended to increase towards the evening in the Aitken and nucleation modes. The accumulation mode GF remained between 1.45 and 1.55 during the daylight hours. The growth factor of $50 \mathrm{~nm}$ particles during non-event days was 1.25 in the morning. In the morning of event days it was considerably higher (1.55). By the evening, the $50 \mathrm{~nm}$ GFs were at the same level (1.4) as compared with the event days.

To conclude, the diurnal cycle of Aitken mode particle hygroscopicity during event and non-event days had different trends. During event days, the water uptake decreased in the afternoon whereas during the non-event days the hygroscopicity increased. The material condensing onto newlyformed particles during their growth period enlarges also the pre-existing Aitken mode. Thus, during the afternoon of the event days, the dominant condensing species was less hygroscopic than the material already present in the Aitken mode particles.

\section{Athens}

The measurement days at Thrakomakedones were divided into days without new particle formation (non event day) and days with secondary aerosol production (event days). The new particle formation days were further separated into two categories based on the amount of urban pollution and meteorological situation. During the polluted events, local wind velocities were low and city plume reached the measurement site at Thrakomakedones making $\mathrm{NO}_{\mathrm{x}}$ concentrations up to 10 times higher than during the clean nucleation event days.

The day-time variation during non-event, polluted and clean event days of median hygroscopic growth factor spec- trum for the classified data is presented in Fig. 10 for $50 \mathrm{~nm}$, 20 and $10 \mathrm{~nm}$ particles. Again, only daytime data were included, since the production of secondary particles was observed to take place only during day-light hours. For the daytime variation, only data points with more than 2 contributing days were considered instead of 3 at Marseille. This is due fewer number of nucleation event days available.

The diurnal variation of the water uptake of $50 \mathrm{~nm}$ particles during event and non-event days is presented in Fig. 10. On average, the growth factors were constant for both cases. The absolute value was considerably lower during the event days (1.4 vs. 1.55). No significant daytime cycle was observed in any category for the $50 \mathrm{~nm}$ size range. For $20 \mathrm{~nm}$ particles a variability during daytime was observed. In the morning of the clean event days, the hygroscopicity of $20 \mathrm{~nm}$ particles was at a minimum of 1.0. During the morning hours, the water uptake increased and was at maximum around noon $(\mathrm{GF}=1.4)$. After this, the hygroscopicity started to decrease and was 1.2 at 19:00.

The hygroscopicity of $10 \mathrm{~nm}$ particles is presented in Fig. 10. The particle concentrations in this size range were close to a detection limit of the HTDMA setup, especially during the non-event days. The changes in the hygroscopicity of $10 \mathrm{~nm}$ and $20 \mathrm{~nm}$ particles are reflected to the properties of condensable vapours as the mode of freshly-formed particles grow through the HTDMA spectrum. During the Athens campaign, new particles typically entered the size distribution between 09:00 and 10:00. During polluted events, the average growth rate was $5.5 \mathrm{~nm} \mathrm{~h}^{-1}$ (Table 2). Considering the times when the geometric mean diameter was approximately at the fixed drysizes of the HTDMA setup, it represents the properties of growing nucleation mode particles as a whole. The water soluble volume fraction at 11 for $10 \mathrm{~nm}$ particles was 1.03 calculated according to Swietlicki et al. (1999). Subsequently the $20 \mathrm{~nm}$ HTDMA data revealed external mixing during polluted events. At noon there was a less hygroscopic mode at 1.25 and more hygroscopic mode at 1.55 approximately in equal proportions. During the course of the afternoon, the growth factors of both modes decreased. At 14:00 the less hygroscopic mode was at $\mathrm{GF}=1.15$ and the more hygroscopic at $\mathrm{GF}=1.4$. After 15:00 the two modes merged at $\mathrm{GF}=1.35$. This corresponds to soluble volume fraction of 0.66. Based on Kulmala et al. (2001), this transforms into mass flux ratio $\left(\mathrm{I}_{1} / \mathrm{I}_{2}\right)$ of 0.65 between insoluble $\left(I_{1}\right)$ and soluble $\left(I_{2}\right)$ material. In other words, the observed soluble volume fraction decrease between $10 \mathrm{~nm}$ and $20 \mathrm{~nm}$ during the nucleation mode growth can be explained, if the insoluble mass flux $\left(\mathrm{I}_{1}\right)$ to the particulate phase was $65 \%$ of the soluble mass flux $\left(\mathrm{I}_{2}\right)$. Thus, the growth due to water soluble components was larger than growth by water insoluble material.

During clean event days, the average growth rate of the nucleation mode was $2.3 \mathrm{~nm} \mathrm{~h}^{-1}$ (Table 2). The soluble volume fraction calculated from the median HTDMA spectra for $10 \mathrm{~nm}$ particles at 13:00 was 1.12 and $20 \mathrm{~nm}$ growth factor 

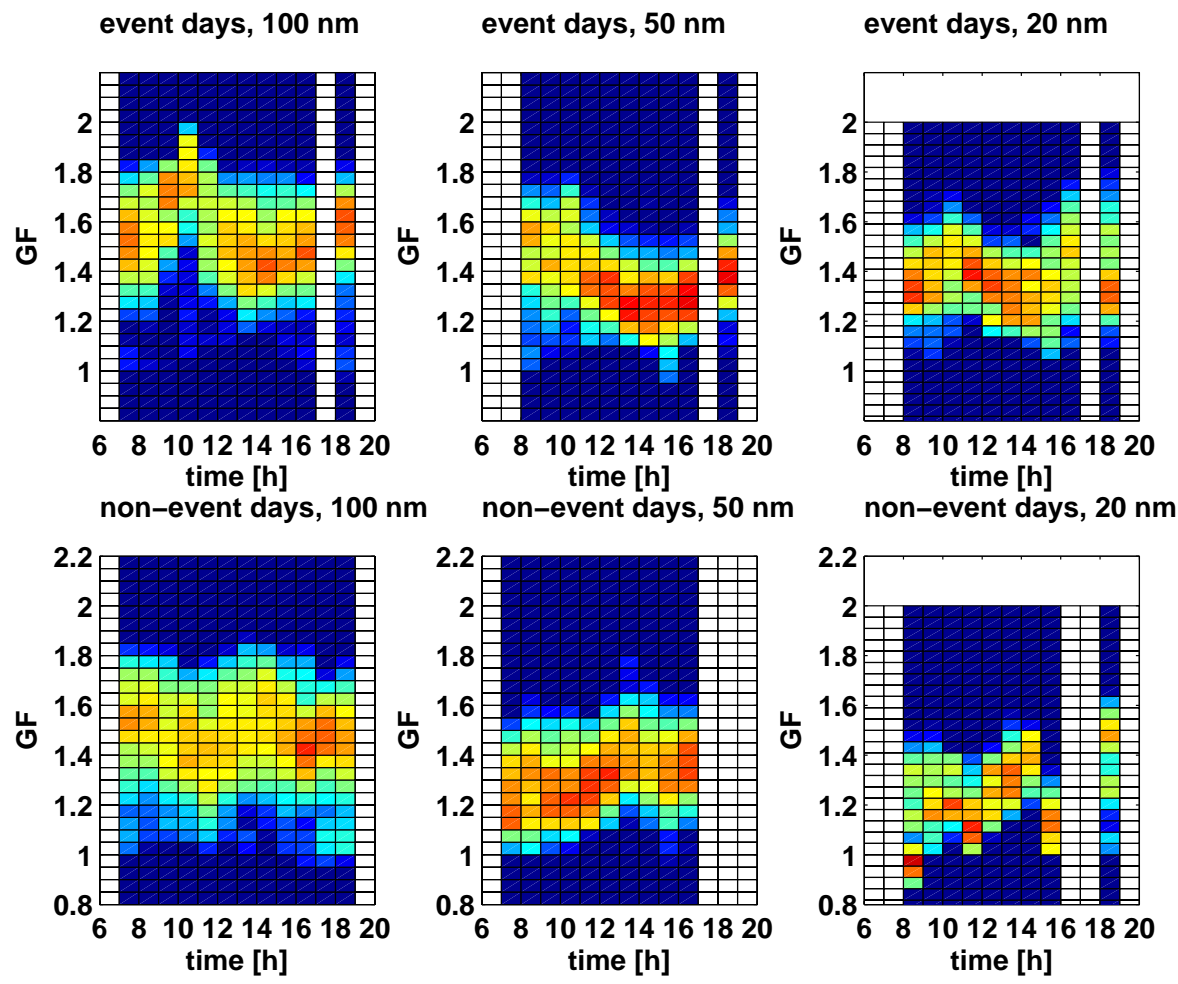

Fig. 9. Daytime median growth factor spectra during new particle formation event days and non-event days for $100 \mathrm{~nm}$, $50 \mathrm{~nm}$ and $20 \mathrm{~nm}$ particle sizes at Plan d'Aups, Marseille.
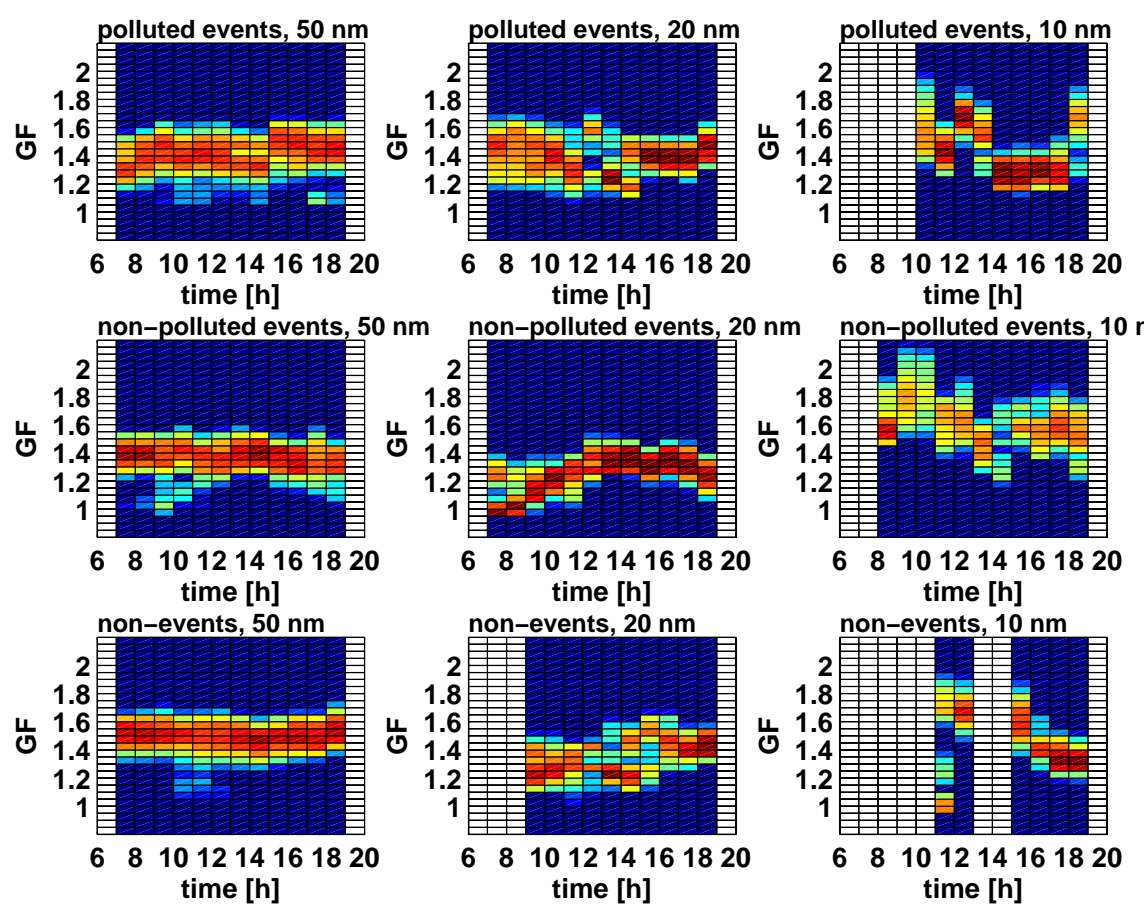

Fig. 10. Daytime median growth factor spectra during new particle formation event days and non-event days for $50 \mathrm{~nm}$, and $20 \mathrm{~nm}$ and $10 \mathrm{~nm}$ particle sizes at Thrakomakedones, Athens. Events days were divided into polluted and non-polluted days based on meterological conditions. 
(GF) at 17:00 was 0.49 . This transforms into the mass flux ratio of $\mathrm{I}_{1} / \mathrm{I}_{2}=1.54$ between the insoluble $\left(\mathrm{I}_{1}\right)$ and soluble $\left(\mathrm{I}_{2}\right)$ material. During the clean event days the growth due to insoluble components was $54 \%$ larger than size increase by condensation of water soluble components.

\section{Conclusions}

The size distributions and hygroscopicity of aerosol particles were measured at two Mediterranean locations in Athens and Marseille regions. Log-normal curves were fitted to the observed distributions. New particle formation was observed during more than $30 \%$ of days at both Athens and Marseille. Also previous investigations at Plan d'Aups, Marseille, during summer 2001 indicated gas-to-particle conversion (Marinoni et al., 2005).

The sub-micron aerosol population at the Mediterranean area can be characterized as a distribution with two or three modes. There was a persistent accumulation mode at both sites. The Athens site was characterized as slightly larger accumulation mode. Aitken $(25-80 \mathrm{~nm})$ and nucleation modes were more variable at both sites.

Urban pollution affected strongly the Athens site. During these pollution episodes Aitken mode particles $\left(\mathrm{D}_{p} 30\right.$ $80 \mathrm{~nm}$ ) dominated particle number concentrations in the submicron range. The fact that the measurement location was in the border of the city induced a strong wind direction dependency on the total particle number concentrations and size distribution parameters.

The hygroscopic properties of aerosol population varied as a function of time of day and particle size. External mixing was observed both at Athens and Marseille. A less hygroscopic mode was present at both sites, with a contribution between $6-10 \%$. More hygroscopic particles had the largest contribution during all observations. The grand-averaged peak value of growth factor varied from 1.3 and 1.45 for $50 \mathrm{~nm}$ particles at Marseille and Athens, respectively, indicating differences in the average chemical composition between the measurement sites.

New particle formation events seemed to be related to sulphuric acid formation and small condensation sink. The higher the condensation sink the higher fraction of clusters will coagulate to pre-existing aerosol particles and they will never grow up to $3 \mathrm{~nm}$. The importance of solar radiation was also seen from the results: there were no events during rainy or cloudy days.

Anthropogenic influence on the properties of newlyformed particles was evident during Athens campaign. As the event days were divided into two categories based on the dominant wind direction and gaseous pollutant levels, hygroscopic growth factor evolution revealed differences between the properties of condensing vapours. In a case of weak anthropogenic influence, the contribution of water insoluble material to nucleation mode growth was larger than that of water insoluble components. On the other hand, during the polluted days the size increase from $10 \mathrm{~nm}$ to $20 \mathrm{~nm}$ was controlled by water soluble components. Corresponding mass flux ratios were 1.54 and 0.65 for clean and polluted event days, respectively. Previously, Stolzenburg et al. (2005) was able to explain almost all the nucleation mode growth by water soluble sulphuric acid in the polluted Atlanta atmosphere. On the other hand, a study by Boy et al. (2005) attributed only $10 \%$ of the observed growth to sulphuric acid in a Boreal forest site.

Our results add to the information on the evolution of aerosol size distribution in the sub-micron size range in the Mediterranean Area. The observed hygroscopic properties and characteristics of new particle formation events gives new insight on atmospheric chemistry and physics near Athens and Marseille. The size distribution and hygroscopicity data set can be used in the regional air quality and global aerosol models.

Acknowledgements. This work was supported by the Academy of Finland and the EU 5th Frame Programme within contract EVK2-CT-2001-00107 through the project "Biogenic Aerosols and Air Quality in the Mediterranean Area" (BOND). Help of D. Robin and the rest of AIRMARAIX staff during the Marseille campaign and J. Bartzis and the staff of NCSR Demokritos during the Athens campaign are greatly appreciated. N. Gounaris (NCSR Demokritos) is acknowledged for production of the maps. NOAA Air Resources Laboratory (ARL) is acknowledged for the provision of the HYSPLIT transport and dispersion model and READY website (http://www.arl.noaa.gov/ready.html) used in this publication. S. Lance is acknowledged for revising the language.

Edited by: A. Nenes

\section{References}

Aalto, P., Hämeri, K., Becker, E., Weber, R., Salm, J., Mäkelä, J. M., Hoell, C., O’Dowd, C. D., Karlsson, H., Hansson, H.C., Väkevä, M., Koponen, I. K., Buzorius, G., and Kulmala, M.: Physical characterization of aerosol particles during nucleation events, Tellus, 53B, 344-358, 2001.

Aklilu, Y. and Mozurkewich, M.: Determination of external and internal mixing of organic and inorganic aerosol components from hygroscopic properties of submicrometer particles during a field study in the Lower Fraser Valley, Aerosol Sci. Technol., 38, 140154, 2004.

Baron, P. and Willeke, K.: Aerosol Measurement: Principles, Techniques, and Applications, 2nd edition, John Wiley and Sons, 2001.

Bastin, S., Drobinski, P., Dabas, A., Delville, P., Reitebuch, O., and Werner, C.: Impact of the Rhône and Durance valleys on seabreeze circulation in the Marseille area, Atmos. Res., 74, 303328, 2005.

Bilde, M. and Svenningsson, B.: CCN activation of slightly soluble organics: the importance of small amounts of inorganic salt and particle phase, Tellus, 56B, 128-134, 2004.

Boy, M., Kulmala, M., Ruuskanen, T. M., Pihlatie, M., Reissell, A., Aalto, P. P., Keronen, P., Dal Maso, M., Hellen, H., Hakola, 
H., Janson, R., Hanke, M., and Arnold, F.: Sulphuric acid closure and contribution to nucleation mode particle growth, Atmos. Chem. Phys., 5, 863-878, 2005,

http://www.atmos-chem-phys.net/5/863/2005/.

Brunekreef, B. and Holgate, S.: Air pollution and health, The Lancet, 360, 1233-1242, 2002.

Cabada, J., Khlystov, A., Wittig, A., Pilinis, C., and Pandis, S.: Light scattering by fine particles during the Pittsburgh Air Quality Study: Measurements and modeling, J. Geophys. Res., 109, D16S03, doi:10.1029/2003JD004155, 2004.

Cachier, H., Aulagnier, F., Sarda, R., Gautier, F., Masclet, P., Besombes, J.-L., Marchand, N., Despiau, S., Croci, D., Mallet, M., Laj, P., Marinoni, A., Deveau, P.-A., Roger, J.-C., Putaud, J.-P., Van Dingenen, R., Dell'Acqua, A., Viidanoja, J., Martins-Dos Santos, S., Liousse, C., Cousin, F., Rosset, R., Gardrat, E., and Galy-Lacaux, C.: Aerosol studies during the ESCOMPTE: an overview, Atmos. Res., 74, 547-563, 2005.

Carrico, C., Kreidenweis, S., Malm, W., Day, D., Lee, T., Carillo, J., McMeeking, G., and Collett Jr., J.: Hygroscopic growth behavior of a carbon-dominated aerosol in Yosemite National Park, Atmos. Environ., 39, 1393-1404, 2005.

Chaloulakou, A., Kassomenos, P., Spyrellis, N., Demokritou, P., and Koutrakis, P.: Measurements of $\mathrm{PM}_{10}$ and $\mathrm{PM}_{2.5}$ particle concentrations in Athens, Greece, Atmos. Environ., 37, 649-660, 2003.

Colbeck, I., Chung, M. C., and Eleftheriadis, K.: Formation and transport of atmospheric aerosol over Athens, Greece, Water Air Soil Pollut. Focus, 2, 223-235, 2002.

Corsmeier, U., Behrendt, R., Drobinski, P., and Kottmeier, C.: The mistral and its effects on air pollution transport and vertical mixing, Atmos. Res., 74, 275-302, 2005.

Cros, B., Durand, P., Cachier, H., Drobinski, P., Frejafon, E., Kottmeier, C., Perros, P., Peuch, V.-H., Ponche, J.-L., Robin, D., Said, F., Toupance, G., and Wortham, H.: The ESCOMPTE program: an overview, Atmos. Res., 69, 241-279, 2004.

Dal Maso, M., Kulmala, M., Riipinen, I., Wagner, R., Hussein, T., Aalto, P., and Lehtinen, K.: Formation and growth of fresh atmospheric aerosols: Eight Years of Aerosol Size Distribution Data from SMEAR II, Hyytiälä, Finland, Boreal Environ. Res., 10, 323-336, 2005.

Draxler, R. and Rolph, G.: HYSPLIT (HYsplit Single-Particle Lagrangian Intregrated Trajectory) model, Website (http://www. arl.noaa.gov/ready/hysplit4.html), NOAA Air Resources Laboratory, Silver Spring, MD., USA, 2003.

Flocas, H., Assimakopoulos, V., Helmis, C., and Güsten, H.: VOC and $\mathrm{O}_{3}$ distributions over the densely populated area of greater Athens, Greece, J. Appl. Meteorol., 42, 1799-1810, 2003.

Flocas, H., Assimakopoulos, V. D., and Helmis, C. G.: An experimental study of aerosol distribution over a Mediterranean urban area, Sci. Tot. Environ. 367, 872-887, 2006.

Grivas, G., Chaloulakou, A., Samara, C., and Spyrellis, N.: Spatial and temporal variation of $\mathrm{PM}_{10}$ mass concentrations within the greater area of Athens, Greece, Water Air Soil Pollut., 158, 357371, 2004.

Hämeri, K., Väkevä, M., Hansson, H.-C., and Laaksonen, A.: Hygroscopic growth of ultrafine ammonium sulphate aerosol measured using an ultrafine tandem differential mobility analyser., J. Geophys. Res., 105, 22 231-22 242, 2000.

Hussein, T., Dal Maso, M., Petäjä, T., Koponen, I., Paatero, P.,
Aalto, P., Hämeri, K., and Kulmala, M.: Evaluation of an automatic algorithm for fitting the particle number size distributions, Boreal Environ. Res., 10, 337-355, 2005.

Janhäll, S. and Hallquist, M.: A novel method for determination of size-resolved, submicrometer particle traffic emission factors, Environ. Sci. Technol., 39, 7609-7615, 2005.

Jokinen, V. and Mäkelä, J. M.: Closed loop arrangement with critical orifice for DMA sheath/excess flow system, J. Aerosol Sci., 28, 643-648, 1997.

Kittelson, D., Watts, W., and Johnson, J.: Nanoparticle emissions on Minnesota highways, Atmos. Environ., 38, 9-19, 2004.

Kulmala, M., Dal Maso, M., Mäkelä, J., Pirjola, L., Väkevä, M., Aalto, P., Miikkulainen, P., Hämeri, K., and O'Dowd, C.: On the formation, growth and composition of nucleation mode particles, Tellus B, 53, 479-490, 2001.

Kulmala, M.: How particles nucleate and grow, Science, 302, 10001001, 2003.

Kulmala, M., Laakso, L., Lehtinen, K., Riipinen, I., Dal Maso, M., Anttila, T., Kerminen, V.-M., Hõrrak, U., Vana, M., and Tammet, H.: Initial steps of aerosol growth, Atmos. Chem. Phys., 4, 25532560, 2004a.

Kulmala, M., Vehkamäki, H., Petäjä, T., Dal Maso, M., Lauri, A., Kerminen, V.-M., Birmili, W., and McMurry, P.: Formation and growth rates of ultrafine atmospheric particles: a review of observations, J. Aerosol Sci., 35, 143-176, 2004b.

Kulmala, M., Petäjä, T., Mönkkönen, P., Koponen, I., Dal Maso, M., Aalto, P., Lehtinen, K., and Kerminen, V.-M.: On the growth of nucleation mode particles: source rates of condensable vapor in polluted and clean environments, Atmos. Chem. Phys., 5, 409416, 2005,

http://www.atmos-chem-phys.net/5/409/2005/.

Laaksonen, A., Hamed, A., Joutsensaari, J., Hiltunen, L., Cavalli, F., Junkermann, W., Asmi, A., Fuzzi, S., and Facchini, M, C.: Cloud condensation nucleus production from nucleation events at a highly polluted region, Geophys. Res. Lett., 32, L06812, doi:10.1029/2004GL022092, 2005.

Marinoni, A., Laj, P., Deveaux, P., Marino, F., Ghermandi, G., Aulagnier, F., and Cachier, H.: Physicochemical properties of fine aerosols at Plan d'Aups during ESCOMPTE, Atmos. Res., 74, 565-580, 2005.

Mertes, S., Schröder, F., and Wiedensohler, A.: The particle detection efficiency curve of the TSI-3010 CPC as a function of temperature difference between saturator and condenser, Aerosol Sci. Technol., 23, 257-261, 1995.

Mönkkönen, P., Koponen, I., Lehtinen, K., Hämeri, K., Uma, R., and Kulmala, M.: Measurements in a highly polluted Asian mega city: observations of aerosol number size distribution, modal parameters and nucleation events, Atmos. Chem. Phys., 5, 57-66, 2005 , http://www.atmos-chem-phys.net/5/57/2005/.

O'Dowd, C.: Biogenic coastal production and its influence on aerosol radiative properties, J. Geophys. Res., 106, 1545-1549, 2001.

Peng, C., Chan, M., and Chan, C.: The hygroscopic properties of dicarboxylic and multifunctional acids: measurements and UNIFAC predictions, Environ. Sci. Tech., 35, 4495-4501, 2001.

Putaud, J.-P., Raes, F., Van Dingenen, R., Brüggemann, E., Facchini, M.-C., Decesari, S., Fuzzi, S., Gehrg, R., Güglin, C., Laj, P., Lorbeer, G., Maenhaut, W., Mihalopoulos, N., Müller, G., 
Querol, X., Rodriguez, S., Schneider, J., Spindler, G., ten Brink, H., Tørseth, K., and Wiedensohler, A.: A European aerosol phenomenology - 2: chemical characteristics of particulate matter at kerbside, urban, rural and background sites in Europe, Atmos. Environ., 38, 2579-2995, 2004.

Rader, D. J. and McMurry, P. H.: Application of the tandem differential mobility analyzer to studies of droplet growth or evaporation, J. Aerosol. Sci., 28, 771-787, 1986.

Rolph, G.: Real-time Environmental Applications and Display sYstem (READY), Website (http://www.arl.noaa.gov/ready/, NOAA Air Resources Laboratory, Silver Spring, MD., USA, 2003.

Sotiropoulou, R., Tagaris, E., Pilinis, C., Andronopoulos, S., Sfetsos, A., and Bartzis, J. The BOND project: Biogenic aerosols and air quality in Athens and Marseille greater areas, J. Geophys. Res., 109, D05205, doi:10.1029/2003JD003955, 2004.

Stier, P., Feichter, J., Kinne, S., Kloster, S., Vignati, E., Wilson, J., Ganzeveld, L., Tegen, I., Werner, M., Balkanski, Y., Schultz, M., Boucher, O., Minikin, A., and Petzold, A.: The aerosolclimate model ECHAM5-HAM, Atmos. Chem. Phys., 5, 11251156, 2005, http://www.atmos-chem-phys.net/5/1125/2005/.

Stolzenburg, M. and McMurry, P.: An ultrafine aerosol condensation nucleus counter, Aerosol Sci. Technol., 14, 48-65, 1991.

Stolzenburg, M. R.: An ultrafine aerosol size distribution measuring system, Ph. D. Thesis, University of Minnesota, 1988.

Stolzenburg, M., McMurry, P., Sakurai, H., Smith, J., Mauldin, R., Eisele, F., and Clement, C.: Growth rates of freshly nucleated atmospheric particles in Atlanta, J. Geophys. Res., 110, D22S05, doi:10.1029/2005JD005935, 2005.

Swietlicki, E., Zhou, J., Berg, O. H., Martinsson, B. G., Frank, G., Cederfelt, S. I., Dusek, U., Berner, A., Birmili, W., Wiedensohler, A., Yuskiewicz, B., and Bower, K. N.: A closure study of sub-micrometer aerosol particle hygroscopic behaviour, Atmos. Res., 50, 205-240, 1999.

Tunved, P., Hansson, H.-C., Kerminen, V.-M., Strom, J., M., D., Lihavainen, H., Viisanen, Y., Aalto, P., Komppula, M., and Kulmala, M.: High natural aerosol loading over boreal forests, Science, 312, 261-263, 2006.
Van Dingenen, R., Raes, F., Putaud, J.-P., Baltensperger, U., Charron, A., Facchini, M.-C., Decesari, S., Fuzzi, S., Gehrig, R., Hansson, H.-C., Harrison, R. M., Hüglin, C., Jones, A., Laj, P., Lorbeer, G., Maenhaut, W., Palmgren, F., Querol, X., Rodriguez, S., Schneider, J., ten Brink, H., Tunved, P., Tørseth, K., Wehner, B., Weingartner, E., Wiedensohler, A., and Wåhlin, P.: A European aerosol phenomenology - I: physical characteristics of particulate matter at kerbside, urban, rural and background sites in Europe, Atmos. Environ., 38, 2561-2577, 2004.

Van Dingenen, R., Putaud, J.-P., Martins-Dos Santos, S., and Raes, F.: Physical aerosol properties and their relation to air mass origin at Monte Cimone (Italy) during the first MINATROC campaign, Atmos. Chem. Phys., 5, 2203-2226, 2005, http://www.atmos-chem-phys.net/5/2203/2005/.

Virkkula, A., Van Dingenen, R., Raes, F., and Hjort, J.: Hygroscopic properties of aerosol formed by oxidation of limonene, alpha-pinene, and beta-pinene., J. Geophys. Res., 104, 35693579, 1999.

Von Klot, S., Peters, A., Aalto, P., Bellander, T., Berglind, N., D'Ippoliti, D., Elosua, R., Hörmann, A., Kulmala, M., Lanki, T., Löwel, H., Pekkanen, J., Picciotto, S., Sunyer, J., Forastriere, F., and the HEAPSS study group: Ambient air pollution is associated with increased risk of hospital cardiac readmission of myocardial infarction survivors in five European cities, Circulation, 112, 3073-3079, 2005.

Väkevä, M., Kulmala, M., Stratmann, F., and Hämeri, K.: Field measurements of hygroscopic properties and state of mixing of nucleation mode particles, Atmos. Chem. Phys., 2, 55-66, 2002, http://www.atmos-chem-phys.net/2/55/2002/.

Wiedensohler, A.: An approximation of the bipolar charge distribution for particles in the submicron range, J. Aerosol Sci., 19, 387-389, 1988.

Winklmayr, W., Reischl, G., Lindner, A., and Berner, A.: A new electromobility spectrometer for the measurement of aerosol size distributions in the size range from 1 to $1000 \mathrm{~nm}$, J. Aerosol Sci., 22, 289-296, 1991. 